UDC 621.43.016

\title{
EXERGY AND ECONOMIC OPTIMIZATION OF COMPLEX POWER SUPPLY SYSTEMS
}

\author{
B. Draganov, Doctor of Technical Sciences, Professor \\ A. Mishenko, Candidate of Technical Sciences, Associate Professor \\ National University of Life and Environmental Sciences of Ukraine
}

E-mail: mavm@ukr.net

\begin{abstract}
The optimization of energy supply system becomes especially important problem in those cases where there are several different energy sources, including, e.g., renewable energy sources, and several energy sinks of different power. This problems can be solved with the use of a graph of exergy and economic expenditures for the pairwise interaction of flows.

The purpose of the study is to specify the concept of exergy schedule and economic costs applied to energy supply systems (ESS).

We shall interpret a graph of the exergy and economic expenditures of an ESS, having an arbitrary structure, as a bipartite graph $Z$ such that the set of its nodes $C$ corresponds to the heating $H$ and heated $C$ flows, and the set of its arcs $D$ to a possible distribution of the exergy and economic expenditures in the corresponding elements of this ESS in the course of interaction between the heating and heated flows.

A symmetric graph represents an oriented graph, whose arcs can be grouped into pairs of parallel but oppositely directed arcs. Such graphs, having no isolated nodes, are convenient for studying complex interrelated systems.

If we have determined the optimal pair of elements (ai, aj), corresponding to the sequence of nodes, beginning from the root of the foretree and finishing by a suspended node, giving a matrix of unit dimension, then the obtained sequence of elements forms a single-contour system with the minimum level of exergy and economic expenditure.

For finding the optimal solution it is advisable to use the method of branches and boundaries, which enables one to improve the solution simpler than with the application of different methods of exergy analysis.
\end{abstract}

Key words: energy supply systems, exergy, symmetric graph

Introduction. An energy supply system represents an assemblage of dissimilar elements with a complex scheme of technological connections [1,2]. The processes of the transformation, transfer, and redistribution of different kinds of energy, accompanied by changes in the parameters of state and flow rates of working media, take place in this system.

Analysis of recent researches and publications. The combination energy sources energy sinks is an integral part of an energy system. For energy supply systems, the 
problem of optimal choice of the complex mentioned above is quite substantial. The optimization problem becomes especially important in those cases where there are several different energy sources, including, e.g., renewable energy sources, and several energy sinks of different power.

As shown in [3, 4], the problems of this class can be solved with the use of a graph of exergy and economic expenditures for the pairwise interaction of flows.

The purpose of the study is to specify the concept of exergy schedule and economic costs applied to energy supply systems (ESS). In this case, we can consider the heat source as a heating (hot) flow, and the heat consumer - as a heated (cold) flow.Let us concretize the concept of a graph of exergy and economic expenditures as applied to energy supply systems (ESS). In this case, we can consider the heat source as a heating (hot) flow and the heat consumer as a heated (cold) flow.

Materials and methods. We shall interpret a graph of the exergy and economic expenditures of an ESS, having an arbitrary structure, as a bipartite graph $\mathrm{Z}=\left(\mathrm{C} \cup \mathrm{H}, \Gamma_{\mathrm{n}}\right)$ $=(C \cup H, D)$ such that the set of its nodes $C \cup H$ corresponds to the heating $H=\left\{h_{1}, h_{2, \cdots}\right.$, $\left.h_{j}, \ldots, h_{m}\right\}$ and heated $C=\left\{c_{1}, c_{2}, \ldots, c_{i}, \ldots, c_{n}\right\}$ flows, and the set of its arcs $D=\left\{h_{i}, c_{i}\right\}, i$ $=1,2 \ldots, \mathrm{m} ; \mathrm{j}=1,2 \ldots, \mathrm{n}$ to a possible distribution of the exergy and economic expenditures in the corresponding elements of this ESS in the course of interaction between the heating and heated flows.

It is worth noting that a bipartite graph has the following property: the set of its nodes $\mathrm{V}$ can be divided into two subsets $V_{1}$ and $V_{2}$ in such a way that each rib of this graph $G$ connects nodes from different subsets (e.g., the ribs of the graph $G$ connect subsets $V_{1}$ and $\mathrm{V}_{2}$ ).

It is easy to show [5] that a graph of exergy and economic expenditures is a simple graph of the form

$$
\begin{gathered}
\mathrm{H} \cap \mathrm{C}=\varnothing, \\
\left(\forall \mathrm{h}_{\mathrm{i}} \in \mathrm{H}\right) \Gamma_{\mathrm{n}} \mathrm{h}_{\mathrm{i}} \in \mathrm{C}, \\
\left(\forall \mathrm{c}_{\mathrm{i}} \in \mathrm{C}\right) \Gamma_{\mathrm{n}} \mathrm{c}_{\mathrm{j}}=\varnothing .
\end{gathered}
$$


A graph of exergy and economic expenditures is an oriented and asymmetric graph. A graph is called asymmetric if it has no automorphisms different from the identical one. Here, the isomorphism of a graph $\mathrm{G}$ onto itself is called its automorphism. Thus, every automorphism of the graph $\mathrm{G}$ is a substitution of the set of nodes $\mathrm{V}$, preserving contiguities.

Moreover, the connectivity of a graph of exergy and economic expenditures has a limited character and obeys the condition

$$
\left(\forall \mathrm{h}_{\mathrm{i}} \in \mathrm{H}\right) \Gamma_{\mathrm{n}} \mathrm{h}_{\mathrm{j}}=\varnothing,\left(\forall \mathrm{c}_{\mathrm{i}} \in \mathrm{C}\right) \Gamma_{\mathrm{n}}^{-1} \mathrm{c}_{\mathrm{j}}=\varnothing .
$$

Consider successively a series of additional definitions. We interpret a covering of a graph of exergy and economic expenditures $\mathrm{Z}=(\mathrm{C} \cup \mathrm{H}, \mathrm{D})$ as such a subset of $\operatorname{arcs} \mathrm{D} \subset$ D for which

$$
\begin{aligned}
& \left.\forall \mathrm{h}_{\mathrm{i}} \in \mathrm{H}, \exists\left(\mathrm{h}_{\mathrm{i}}, \mathrm{c}_{\mathrm{i}}\right) \in \overline{\mathrm{D}} \mid \mathrm{h}_{\mathrm{i}}, \mathrm{c}_{\mathrm{j}}\right) \subset \mathrm{D}+\mathrm{h}_{\mathrm{i}} ; \\
& \left.\forall \mathrm{c}_{\mathrm{j}} \in \mathrm{C}, \exists\left(\mathrm{h}_{\mathrm{i}}, \mathrm{c}_{\mathrm{i}}\right) \in \overline{\mathrm{D}} \mid \mathrm{h}_{\mathrm{i}}, \mathrm{c}_{\mathrm{j}}\right) \subset \mathrm{D}-\mathrm{h}_{\mathrm{i}} .
\end{aligned}
$$

It is easy to see that relations (5) and (6) represent the necessary and sufficient condition of the existence of a covering of a graph of exergy and economic expenditures, i.e., a graph of exergy and economic expenditures always possesses a covering. The covering represents combinatorial configurations connected by the multivalued mapping of one set onto another. In the problems of coverings, the possibilities of constructing efficient algorithms for the solution of these problems are studied. This means that, for each heating and each heated flow, one can always find at least one flow with which the flow under consideration can enter the process of heat exchange.

A covering $\mathrm{D}_{0} \subset \mathrm{D}$ is minimum if

$$
\forall \overline{\mathrm{D}} \subset \mathrm{D},\left|\overline{\mathrm{D}}_{0}\right| \leq|\overline{\mathrm{D}}| \text {. }
$$

In the general case, we have

$$
|\mathrm{H}| \leq\left|\mathrm{D}_{0}\right| ; \quad|\mathrm{C}| \leq\left|\mathrm{D}_{0}\right| .
$$


As applied to an actual ESS, conditions (8) indicate that the number of interacting couples heat source - heat consumer, being subject to consideration in the synthesized ESS, cannot be smaller than the number of elements of greater of the sets $|\mathrm{C}|$ or $|\mathrm{H}|$.

In the Boolean-matrix presentation, the minimum covering represents a collection of unities such that any row and any column of the matrix contains at least a single element from this collection, and the total number of elements of this collection is minimum.

A Boolean function of $n$ arguments can be assigned with the help of a subset of nodes where this function is equal to unity. This subset is written in the form of a matrix whose rows represent the collections of values of the arguments of this Boolean function.

A matching of a graph of exergy and economic expenditures $\mathrm{Z}=\left(\mathrm{C} \cup \mathrm{H}, \Gamma_{\mathrm{n}}\right)=$ $(\mathrm{C} \cup \mathrm{H}, \mathrm{D})$ is interpreted as a one-to-one mapping $\Gamma_{\mathrm{v}}$ with a number of $\operatorname{arcs} \mathrm{V} \subset \mathrm{D}$ such that

$$
\left(\forall \mathrm{h}_{\mathrm{i}} \in \mathrm{H}^{*}\right) \Gamma_{\mathrm{v}} \mathrm{h}_{\mathrm{i}} \subset \Gamma_{\mathrm{n}} \mathrm{h}_{\mathrm{i}},
$$

or $\left(\forall c_{j} \in C^{*}\right) \Gamma_{\mathrm{v}} \mathrm{c}_{\mathrm{j}} \subset \Gamma_{\mathrm{n}}^{-1} \mathrm{c}_{\mathrm{j}}$,

$\mathrm{i}=1,2, \ldots, \mathrm{m} ; \mathrm{j}=1,2, \ldots, \mathrm{n}$,

where the subsets $\mathrm{C}^{*}$ and $\mathrm{H}^{*}$ satisfy the conditions

$$
\mathrm{C}^{*} \subset \mathrm{C} ; \mathrm{H}^{*} \subset \mathrm{H} ;\left|\mathrm{C}^{*}\right|=\left|\mathrm{H}^{*}\right| \text {. }
$$

Hence, the numbers of heat sources and heat consumers in the matching under consideration have to be equal to one another. The necessary and sufficient condition of the existence of a matching (according to the Koenig-Hall theorem) is

$$
\left(\forall \mathrm{H}^{*} \subset \mathrm{H}\right)\left|\Gamma_{\mathrm{n}} \mathrm{H}^{*}\right| \geq\left|\mathrm{H}^{*}\right| .
$$

As follows from the Koenig - Hall theorem, if the elements of a rectangular matrix are unities and zeros, then the minimum number of lines containing all unities is equal to the maximum number of unities which can be chosen in such a way that, among them, one cannot find two unities located on the same line.

A matching $\mathrm{V}_{0} \subset \mathrm{D}$ is maximum if

$$
(\forall \mathrm{V} \subset \mathrm{D})\left|\mathrm{V}_{0}\right| \geq|\mathrm{V}|,
$$

i.e., the maximum possible number of couples heat source - heat consumer is taken into account in this matching. Condition (11) guarantees consideration of the entire set of 
heat sources in finding the maximum matching. In order to guarantee such a consideration for the entire set $\mathrm{C}$ of heat consumers as well, the condition

$$
\left(\forall \mathrm{C}^{*} \subset \mathrm{C}\right)\left|\Gamma-\ln \mathrm{C}^{*}\right| \geq\left|\mathrm{C}^{*}\right|
$$

has to be satisfied. Conditions (11) and (13) imply that $|\mathrm{C}|=|\mathrm{H}|$.

In actual ESS, both cases $|\mathrm{C}| \leq|\mathrm{H}|$ and $|\mathrm{C}|>|\mathrm{H}|$ are possible, and the variant $|\mathrm{C}|>|\mathrm{H}|$ can be met much more often (for example, the heat supply of several hundreds of consumers from a single regional boiler plant). Then, in finding the maximum matching, it is necessary to introduce an additional number of flows (fictitious) leading to $|\mathrm{C}|=|\mathrm{H}|$ (e.g., a single regional boiler plant is represented as a fictitious set of several hundreds of small boiler plants for the corresponding heat consumers).

The maximum matching is always complete. The converse proposition in the general case is incorrect.

We interpret a support of a graph of exergy losses $\mathrm{Z}=\left(\mathrm{C} \cup \mathrm{H}, \Gamma_{\mathrm{n}}\right)$ as such a set $\mathrm{S} \subset$ $\mathrm{H} \subset \mathrm{C}$ for which

$$
\forall\left(\mathrm{h}_{\mathrm{i}} \mathrm{c}_{\mathrm{j}}\right) \subset \mathrm{D} \mid \mathrm{h}_{\mathrm{j}} \subset \mathrm{S}, \text { or } \mathrm{c}_{\mathrm{j}} \subset \mathrm{S},
$$

i.e., at least one of the nodes of each arc of this graph is included to the set $\mathrm{S}$.

The support $\mathrm{S}_{0} \subset \mathrm{S}$ of a graph $\mathrm{Z}=(\mathrm{C} \cup \mathrm{H}, \mathrm{D})$ is minimum if

$$
\forall \mathrm{S} \subset \mathrm{H} \cup \mathrm{C},\left|\mathrm{S}_{0}\right| \leq|\mathrm{S}| .
$$

As applied to the synthesized ESS, the minimum support of a graph $\mathrm{Z}==\left(\mathrm{C} \cup \mathrm{H}, \Gamma_{\mathrm{n}}\right)$ represents a set $\mathrm{S}_{0} \subset \mathrm{H} \cup \mathrm{C}$ of heat sources and consumers with the minimum total number of elements $S_{0}=\min |S|$ such that the number of variants of their joins both between themselves and with the remaining set $\left(\mathrm{C} \cup \mathrm{H}-\mathrm{S}_{0}\right)$ proves to be maximum. In other words, each of the subject couples heat source - heat consumer in the ESS will include at least one of the elements of the set $\mathrm{S}_{0}$. Furthermore, as follows from the Koenig theorem,

$$
\left|S_{0}\right|=\left|V_{0}\right| \text {. }
$$

Equality (16) serves as a basis in the construction of an algorithm for finding the minimum support of a graph of exergy expenditures. 
Results and discussion. Consider the matrix form of an algorithm for the optimal synthesis of a single-loop circular heat supplying system [6,7], based on the method of finding the Hamiltonian contour [8] of the symmetric graph of thermal and economic expenditures $Z=(A, U)$ shown in Fig. 1 .

Recall that a route (contour) is called a Hamiltonian chain (Hamiltonian cycle) if it contains all nodes of the graph and passes through each of them once. A series of conditions of the existence of Hamiltonian cycles is well known: the graph does not have loops and multiple ribs, and the numbers of its nodes $n$ and ribs $m$ satisfy the conditions $n \geq 3 m \geq 0,5\left(n^{2}-3 n+6\right)$.

A symmetric graph is node- and rib-symmetric, i.e., any pair of its nodes is similar, and any pair of its ribs is similar as well.

It represents an oriented graph, whose arcs can be grouped into pairs of parallel but oppositely directed arcs. Such graphs, having no isolated nodes, are convenient for studying complex interrelated systems.

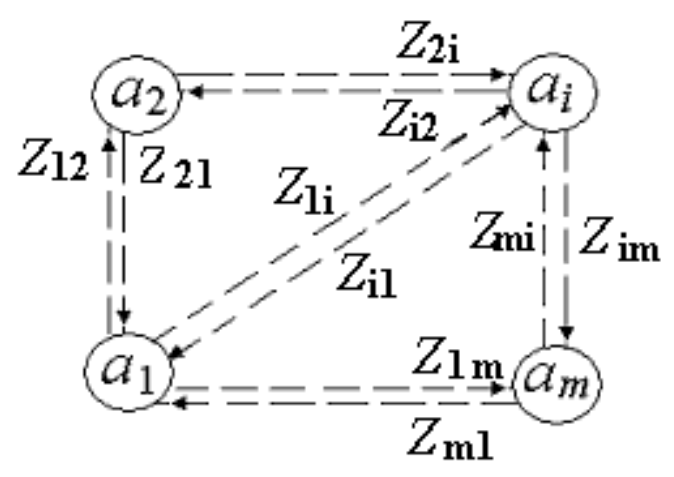

Fig. 1. A symmetric graph of exergy and economic expenditures for a circular energy supply system

For finding the optimal solution, researchers prefer to apply the method of branches and boundaries, which makes it possible to obtain a solution simpler than with the use of different methods of exergy analysis $[6,7]$. The thermal and economic estimate of the interaction of a couple of flows $i j$ is given by

$$
Z_{\Sigma}^{\min }=\min \sum_{i} \sum_{j} Z_{i j}
$$


The corresponding graph of energy and economic expenditures is presented in Fig. 2. The possible values of exergy and economic expenditures in the system are equal to $Z_{i j}=Z$ $\left(a_{i}, a_{j}\right), \forall a_{i} \in A, \forall a_{j i} \in A$, where $\forall$ is the matrix of exergy and economic expenditures of dimension $m \times m$ (Fig. 3).

The value of the sum $Z_{\Sigma}^{0}=\sum_{i} Z_{i}^{\min }+\sum_{j} Z_{j}^{\min }$ gives the lower boundary of the set of solutions.

If we have determined the optimal pair of elements $\left(a_{i}, a_{j}\right)$, corresponding to the sequence of nodes, beginning from the root of the foretree and finishing by a suspended node, giving a matrix of unit dimension, then the obtained sequence of elements forms a singlecontour system with the minimum level of exergy and economic expenditures.

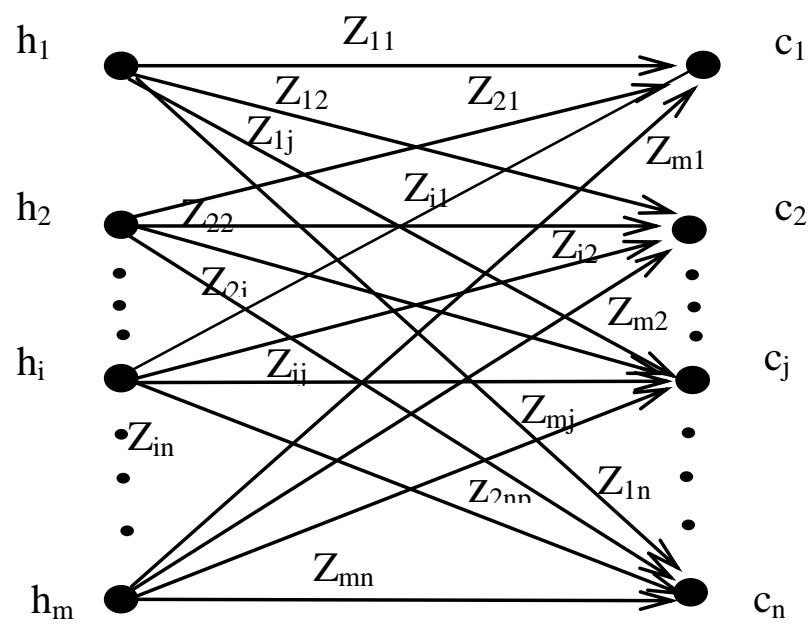

Fig. 2. A graph of exergy and economic expenditures

\begin{tabular}{l|llllll}
\multicolumn{1}{c}{} & $a_{1}$ & $a_{2}$ & $\ldots$ & $a_{i}$ & $\ldots$ & $a_{m}$ \\
\cline { 2 - 7 } & $Z_{11}$ & $Z_{12}$ & $\ldots$ & $Z_{1 j}$ & $\ldots$ & $Z_{1 m}$ \\
$a_{2}$ & $Z_{21}$ & $Z_{22}$ & $\ldots$ & $Z_{2 j}$ & $\ldots$ & $Z_{2 m}$ \\
$\ldots$ & $\ldots$ & $\ldots$ & & $\ldots$ & & $\ldots$ \\
$a_{i}$ & $Z_{i 1}$ & $Z_{i 2}$ & $\ldots$ & $Z_{i j}$ & $\ldots$ & $Z_{i m}$ \\
$\ldots$ & $\ldots$ & $\ldots$ & & $\ldots$ & & $\ldots$ \\
$a_{m}$ & $Z_{m 1}$ & $Z_{m 2}$ & $\ldots$ & $Z_{m j}$ & $\ldots$ & $Z_{m m}$ \\
\cline { 2 - 7 } & & & & & &
\end{tabular}

Fig. 3. A matrix of thermal and economic expenditures corresponding to the graph of thermal and economic expenditures in Fig. 1 
Conclusions and perspectives. For finding the optimal solution (Fig. 3), it is advisable to use the method of branches and boundaries, which enables one to improve the solution simpler than with the application of different methods of exergy analysis [9].

\section{References}

1. Moiseev, N. N. (1981). Matematicheskiye zadachi sistemnogo analiza [Mathematical Problems of Systems Analysis]. Moscow: Nauka, 488.

2. Popyrin, L. S., Samusev, V. I., Epel'shtein V. V. (1981). Avtomatizatsiya matematicheskogo modelirovaniya teploenergeticheskikh ustanovok [Automation of the Mathematical Modeling of Thermal Power Plants]. Moscow: Nauka, 236.

3. El-Sayed, Y. (1999). Revealing the cost efficiency trends of the design concepts of energy-intensive systems. Energy Convertion and Management, 40, 1599 - 1615.

4. Wu, C., Nikulshin, V. (2000). Method of thermoeconomical optimization of energy intensive systems with linear structure on graphs. International Journal of Energy Research, 24, $615-623$.

5. Nikulshin, V., Nikulshina, V., Wu, C., Bailey, M. (2002). Method of thermoeconomical optimization on graph of energy intensive systems with pair interplay of flows. Proceedings of the 15th International Conference on Efficiency, Cost, Optimization, Simulation and Environmental Aspects of Energy Systems, Berlin, 1477 1484.

6. Nikulshin, V., Andreev, L. (1999). Energy efficiency of complex systems // in: Proceedings of the International Conference on Ocean Technology and Energy, OTEC/DOWA'99, Imari, Japan, 162 - 167.

7. Nikulshin, V., Wu, C. (1999). Method of thermodynamic analyses and optimization of energy flow graphs // in: Proceedings of the IASTED International Conference on Power and Energy Systems, Las Vegas, Nevada, USA, 489 - 491.

8. Ore, O. (1968). Theory of Graphs, Moscow: Nauka, 352.

9. Harary, F. (1995). Graph Theory. New Delhi: Narosa Publishing House.

10. Barton, P. L., Allagor, R. J., Feehery, W. F., Galan, S. (1998). Dynamic optimization in a discontinuous world. Ind. Chem. Res., 37, $966-981$.

\section{ЕКСЕРГО-ЕКОНОМІЧНА ОПТИМІЗАЩІЯ КОМПЛЕКСНИХ СИСТЕМ ЕНЕРГОПОСТАЧАННЯ}

\section{Б. Х. Драганов, А. В. Міщенко}

Анотація. Оптимізація системи енергопостачання стає особливо важливою проблемою в тих випадках, коли існує кілька різних джерел енергії, включаючи, наприклад, відновлювані джерела енергії та кілька об'єктів різної потужності. Ці проблеми можна вирішити, використовуючи граф ексергї̈ та економічних витрат для попарної взаємодії потоків.

Метою дослідження є конкретизачія конщепиії графа ексергій та економічних витрат, що застосовуються до систем енергопостачання (СЕП). 
Ми будемо інтерпретувати граф ексергї та економічних витрат СЕП, який має довільну структуру, як дводольний граф $Z$, такий, щуо набір його вузлів $C$ відповідає нагріванню $H$ i нагрітим потокам $C$, а сукупність його дуг $D$ можливому розподілу ексергії та економічних витрат у відповідних елементах даної СЕП під час взаємодії між граючим потоками та потоком, щь нагрівається.

Симетричний граф є орієнтованим графом, дуги якого можна згрупувати в пари паралельних, але протилежно спрямованих дуг. Такі графи, що не мають ізольованих вузлів, зручні для вивчення складних взаємопов'язаних систем.

Якщо ми визначимо оптимальну пару елементів ( $\left.a_{i}, a_{j}\right)$, щзо відповідає послідовності вузлів, починаючи від кореня дерева і закінчуючи підвішеним вузлом, які складають матрицю одиничної розмірності, то отримана послідовність елементів утворює одноконтурну систему з мінімальним рівнем ексергії та економічних витрат.

Для пошуку оптимального рішення доцільно використовувати метод гілок та меж, який дозволяє вдосконалити рішення простіше, ніж із застосуванням різних методів аналізу ексергії.

Ключові слова: система енергопостачання, ексергія, симетричний граф

\section{ЭКСЕРГО-ЭКОНОМИЧЕСКАЯ ОПТИМИЗАЦИЯ КОМПЛЕКСНЫХ СИСТЕМ ЭНЕРГОСНАБЖЕНИЯ}

\section{Б. Х. Драганов, А. В. Мищенко}

Аннотация. Оптимизация системы энергоснабжения становится особенно важной проблемой в тех случаях, когда существует несколько различных источников энергии, включая, например, возобновляемые источники энергии и несколько объектов различной мощности. Эти проблемы можно решить, используя граф эксергии и экономических затрат для попарного взаимодействия потоков.

Целью исследования является конкретизация конџепџии графа эксергии и экономических затрат, применяемые к системам энергоснабжения (СЭС).

Mы будем интерпретировать граф эксергии и экономических затрат СЭП, имеющий произвольную структуру, как двухдольный граф Z, такой, что набор его узлов C соответствует нагреву $H$ и нагретым потокам $C$, а совокупность его дуг $D$ - возможному распределения эксергии и экономических затрат $в$ соответствующих элементах данной СЭС при взаимодействии между греющим и нагреваемым потоками.

Симметричный граф представляет собой ориентированный граф, дуги которого можно сгруппировать в пары параллельных, но противоположно направленных дуг. Такие графы, не имеющие изолированных узлов, удобны для изучения сложных взаимосвязанных систем.

Если мы определим оптимальную пару элементов $\left(a_{i}, a_{j}\right)$, соответствуюшую последовательности узлов, начиная от корня дерева и заканчивая подвешенным узлом, которые составляют матрииу единичной размерности, то полученная последовательность элементов образует одноконтурную систему с минимальным уровнем эксергии и экономических затрат. 
"Енергетика і автоматика", №5, 2020 р.

Для поиска оптимального решения цуелесообразно использовать метод ветвей и границ, который позволяет усовершенствовать решение проще, чем с применением других методов анализа эксергии.

Ключевые слова: система энергоснабжения, эксергия, симметричный граф 